\title{
From academic science to political hot potato: climatic change, risk and policy relevance
}

\author{
Barrie Pittock
}

Received: 11 February 2010 / Accepted: 11 February 2010 / Published online: 19 May 2010

(C) The Author(s) 2010. This article is published with open access at Springerlink.com

\begin{abstract}
Climate change is now a hot political topic that blurs the boundary between policy relevant and policy prescriptive (as contained for example in the avowed stance of the Intergovernmental Panel on Climate Change). The growing political relevance of climate change science necessarily places a premium on timely advice and on risk assessment and management. What is the role of climate scientists in that new situation?
\end{abstract}

When Climatic Change was founded in 1975 (first issue published in 1977) the topic of climatic change was just emerging from the academic realms of paleoclimate to one that just might have relevance to the future of civilisation. Past climatic changes have great significance for the evolution of landforms, plant and animal species and the eventual emergence of organized human societies. Present and especially possible future climate change on the other hand has great significance for future societal development. Future climatic changes will require adaptation of human societies to cope with changing agricultural and other resources and for such societies to cope with changing sea level and extreme events.

Further, the possibility that human actions might influence climate on a local or global scale requires that humans consider what such influence might be, and whether it would be desirable or not. Our understanding of climatic change thus begins to bear directly on the desirability of various forms of human activity, and thus to impact on policy.

The idea that human activities might affect climate followed from John Tyndall's demonstration in 1859 that methane and carbon dioxide control the Earth's surface air temperature by absorbing infra-red or heat radiation. This led Svante Arrhenius

This essay is in part drawn from the author's book "Climate Change: The Science, Impacts and Solutions" (CSIRO Publishing and Earthscan, 2009).

B. Pittock $(\bowtie)$

CSIRO, Marine \& Atmospheric Research, Private Bag 1, Aspendale, VIC 3195, Australia

e-mail: barrie.pittock@csiro.au 
(1896) to suggest that increasing $\mathrm{CO}_{2}$ from industrial activity could lead to a warming of the Earth's climate. GS Callendar further developed this idea in 1938 (Callendar 1938), but it was not until the late 1950s that Charles Keeling of the Scripps Institution of Oceanography put the issue firmly on the map after establishing the first $\mathrm{CO}_{2}$ monitoring stations at Mauna Loa and the South Pole (Keeling 1960). It was Revelle and Suess (1957) of Scripps who famously said:

Human beings are now carrying out a large scale geophysical experiment of a kind that could not have happened in the past nor be reproduced in the future. Within a few centuries we are returning to the atmosphere and oceans the concentrated organic carbon stored in sedimentary rocks over hundreds of millions of years.

By the early 1970s, however, an observed cooling since the 1950s in the northern hemisphere led to some concern that a prolonged cooling trend could lead to another glaciation through the snow albedo feedback (Federal Council for Science and Technology 1974).

Wally Broecker prophetically commented in 1975 (Broecker 1975) that:

... a strong case can be made that the present cooling will, within a decade or so, give way to pronounced warming induced by carbon dioxide. Once this happens, the exponential rise in the atmospheric carbon dioxide content will tend to become a significant factor and by early next century will have driven the mean planetary temperature beyond the limits experienced during the last 1000 years.

The cooling was indeed temporary, and most likely due to a rapid increase in tropospheric aerosols due to post WWII industrialisation with sulphur-rich fossil fuels. The World Meteorological Organisation (WMO) in 1976 (WMO 1976) stated that short-term climate changes might be due to natural or man-made causes, which they said required urgent attention and further study.

It was not until the WMO's First World Climate Conference in Geneva in 1979 (WMO 1979) that international concern was first expressed that increasing $\mathrm{CO}_{2}$ could lead to a gradual warming of the lower atmosphere and that the world should try to 'foresee and prevent potential man-made changes in climate that might be adverse to the well-being of humanity'.

By the 1980s it was clear that the cooling trend had ended, and many of the scientists who had been concerned about a cooling (including our esteemed editor Steve Schneider) demonstrated their openness to new information by changing their minds (see account in Chapter 1 of Schneider 2009). Continuing increases in greenhouse gas concentrations, and a realisation that the effective lifetime of $\mathrm{CO}_{2}$ in the atmosphere was much longer than that of particulates, making for a greater cumulative warming effect, meant that by the early 1980s there was a growing scientific interest in assessing the likelihood and magnitude of global warming.

Indeed, a conference of scientists at Villach in Austria in October 1985, which was sponsored by the non-governmental International Council of Scientific Unions along with the WMO and the United Nations Environment Program (UNEP) agreed to a statement that raised the first collective scientific warning: '.. it is now believed that in the first half of the next century a rise in global mean temperature could occur which is greater than any in human history.' (Villach Conference 1985). 
Also in 1986, the Scientific Committee on Problems of the Environment (SCOPE), a committee of the International Council of Scientific Unions, issued a major report entitled The Greenhouse Effect, Climate Change and Ecosystems, which reinforced the concern about global warming (SCOPE 1986). The SCOPE report concluded that if the observed rate of increase of carbon dioxide continued, it would reach double pre-industrial values towards the end of the twenty-first century, and this would lead to global average warming in the range $1.5-5.5^{\circ} \mathrm{C}$, with associated global average sea-level rise in the range $20-165 \mathrm{~cm}$. The report went on to discuss possible impacts on agriculture, forests and ecosystems.

By 1988 this concern had turned into a demand for action to reduce carbon dioxide emissions, adopted by over 300 scientists at a United Nations sponsored 'Conference on the Changing Atmosphere' in Toronto in 1988 (Toronto 1988). This called for an initial reduction in carbon dioxide emissions of $20 \%$ by 2005 , stating that

Humanity is conducting an unintended, uncontrolled, globally pervasive experiment whose ultimate consequences could be second only to a global nuclear war.

In response to these concerns, the WMO and the United Nations Environment Program (UNEP) set up the Intergovernmental Panel on Climate Change (IPCC) in 1988. The initial brief of the IPCC was to report to the Second World Climate Conference in November 1990, and the United Nations General Assembly, on 'the scientific information that is related to the various components of the climate change issue ...' and 'formulating realistic response strategies for the management of the climate change issue.'

As we all know, the IPCC has indeed been busy over the last 20 years, issuing four major scientific assessments and many other special reports (IPCC 2009). The IPCC has organised these major assessments each into three volumes based on three Working Groups, one on "the physical science basis" of concern, the second on the "impacts, adaptation and vulnerability", and the third on "mitigation of climate change".

The IPCC, in its instruction to authors, has been careful to emphasise that reports should be "policy-relevant but not policy-prescriptive". This apolitical stance recognises two things:

1. that for the conclusions to be accepted they need to eschew decision-making about contentious policy issues, but rather set out the possibilities (including policy options) and their possible consequences, and

2. that the conclusions should follow from the science and avoid making valueladen choices, especially in areas outside the areas of expertise of the scientists involved.

This is not just a matter of the reports being accepted as objective and unbiassed by the governments to whom they are addressed, but also that they be accepted by the general public that in democracies determines governments and their policies.

As we now know, this issue of objectivity and credibility has been exploited by many so-called climate change 'sceptics' to discredit the science and any policies to reduce greenhouse gas emissions. Essentially the sceptics have done this by highlighting any objectively admitted uncertainties, distorting and exaggerating their 
significance. They have argued that uncertainty is a reason not to act, whereas in a responsible risk management framework it may well be a reason to act.

Given the wide range of views and self-interests of member countries, a problem area in the IPCC process is the requirement that member countries sign off on the wording of the 'Summaries for Policymakers'. This has led to adoption by consensus of the country delegates, which is made easier by avoidance by the scientific authors of any language or conclusions that might sound alarming, or which might by logical extension into decisionmaking harm a given county's self-perceived national interests. This has had the effect of favouring an emphasis on mid-range projections where there are ranges of possibilities, and an unwillingness to assign probabilities to or make order of magnitude estimates of possible but as yet unmodelled positive feedback effects. This tendency is made worse by many scientists unfamiliar with policy decision-making processes and who do not take a risk management approach. Emphasising the mid-range outcome is the lowest common denominator approach.

This is likely to apply especially to presently hard-to-quantify outcomes such as the possible onset of serious positive feedbacks (such as large methane emissions from melting permafrost or marine methane hydrates) or of extreme sea-level rise projections that could arise from rapid disintegration of the Greenland or Antarctic ice sheets.

Another major problem with the series of IPCC Assessments has been the protracted nature of the writing and review process. This process is of course valuable in ensuring that summaries and conclusions are in fact well-based and objective. However, it has meant that rapidly developing topics of policy importance are often out of date by the time of publication or shortly after.

An example is the apparent rapidity of observed climatic changes such as the poleward extension of the Hadley Circulation and associated poleward shifts of the mid-latitude rainfall belts. These are happening about two or three times as fast as in the climate models, and this is vitally important for drought and flood frequencies and water supply for many millions of people. Another example in the case of the Fourth Assessment has been the far more rapid loss of Arctic sea ice than was projected in the report.

Another example where lack of a timely risk management approach has led to a failure to recognise a policy-relevant conclusion is that the climate science community has in general focussed on possible climate changes and impacts several decades ahead rather than on present impacts, despite a century of global warming. This has serious policy-relevance because there is still a widely held perception that climate change is not an immediate problem but one for future generations (if a problem at all). While inter-generational equity makes the long-term impacts a moral issue, that is not persuasive with many people who argue, rightly or wrongly, that future generations will be able to cope as they will have new technology and be wealthier. That argument does not hold up if damaging impacts are already happening, or we are approaching some near tipping point at which damages will rapidly increase.

The issue of possible damages now from increasingly severe or frequent extreme events centres on the attribution of present extreme events to human-induced climate change rather than to normal climate variability. It is a difficult one because the scientific community and IPCC have by now assigned a high likelihood to the causal connection between the experienced global warming trend and enhanced greenhouse 
emissions, but necessarily place less confidence on attribution of individual extreme events to climate change. The lack of risk management insight mitigates against highlighting the experience of extremes in the present changed climate simply because attribution is uncertain.

My argument, based on regional Australian experience, is that extreme events of the sort to be expected from global warming are already happening more frequently and with greater intensity than they were, and we can estimate the costs of these changes in terms of lives lost and damages caused. My case for Australia rests on the recent series of widespread and highly damaging wildfires in the last decade, record heatwaves, widespread drought, and coastal impacts either already experienced or anticipated under more stringent planning rules and higher insurance costs (with consequent loss of property values). Published estimates of damages run into hundreds of lives and billions of dollars annually.

The policy-relevant conclusion is that there is a high risk (measured as the product of probability times consequences) that present damages due to extreme events in Australia are in fact heightened by climate change trends. The logical policy implication, if that ongoing risk is judged to be unacceptable, is that the situation needs to be remedied by both adaptation to a new regime of extreme events and reduction in greenhouse gas emissions that are at the root of the problem. Where does the scientist stop giving advice-at the causal link between cause and effect, or at the logical policy implications which may be clear to us as scientists, but not so clear to decisionmakers? If increased wildfire frequency and intensity is to be expected, how does the scientific conclusion affect, for example, fire management policies? Should we point to, and perhaps even spell that out?

I mention this as both an example of the problem of the scientific method and of policy-relevance. I drafted a well-documented paper on the present costs of extreme events in Australia in early October 2009 (Pittock 2009, submitted for publication), with a view to getting it published quickly in the refereed literature so that it could be cited in public discourse aimed at influencing the Copenhagen climate talks in December 2009. There were three scientific report series or journals that promised rapid publication. However, one sent it to reviewers in an early draft and the referees queried the attribution issue. Even though I fixed that (to my satisfaction), it was by then too late for a 2009 issue. Another rejected it as too long, while the third rejected it because the editor judged it to be a review rather than original work. It appears, from this admittedly limited experience, that the scientific system is not at present geared to rapid publication of refereed and highly policy-relevant findings.

A second general problem is that research organisations that employ scientists, be they government-funded laboratories or other bodies, are in some cases loathe to publish policy-relevant work if it might be construed to be policy-prescriptive. Some research organisations have policies and charters on what is appropriate, but its application is not always clear. Individual scientists (or indeed their supervisors or referees) can be torn between a perceived public duty to make the policy-relevance of their findings known, and the need to avoid, as scientists, making value judgements as to the most appropriate policy.

We all know of good scientists who have ventured into policy-advice and got rapped over the knuckles for their trouble. But where do we draw the line? Conventionally there is a problem with scientists in government-funded laboratories who air views on specific policies, especially if their advice goes against government 
policy. There are real problems here regarding relevant expertise, how we deal with uncertainties and conflicting views, and exactly where the line is drawn between policy-relevance and policy advocacy.

I believe the answer lies at least partly in a broader acceptance of a riskmanagement approach by scientists, their employers, politicians and the general public. For example, in the case of the impacts up to now of increases in extreme events and its relevance to climate change policy, it should be reasonable and persuasive to point to an increased likelihood of, and the costs of, more droughts, wildfires, heat waves and coastal impacts from the climate change and sea-level rise experienced to date. People should be able to make their own value judgements as to the policy implications based on some notional estimate of the probabilities, say a $50 \%$ chance that each of those extremes has been exacerbated by global warming.

More generally, the urgency of climate policy decisions militates against the best scientific advice being brought to bear unless scientists are prepared to chance their arms at probabilistic estimates of likely outcomes, whether it is of multi-meter sealevel rises or of hitting some tipping point. We have, I believe, a responsibility to make such possibilities part of the background information for decision-makers, not to sit on our hands until we have "better quantified" estimates or gone through a protracted refereeing process that in the case of some scientific journals can lead to a gap of a year or more between submission and publication of a paper. Peer review is a desirable discipline that avoids poorly based conclusions from gaining too much credibility, but where it concerns urgent policy-relevant material the process needs to be speeded up.

The real world does not operate on certainties: it lives with uncertainties and makes decisions on the basis of conscious or unconscious assessments of probabilities, often without waiting for expert advice. It is better that we provide timely informed estimates than that decision-makers not expert in the areas make their own guesses. It is a matter of responsible risk management.

And it behoves scientific journals, and employers of scientists, to recognise the urgency of providing informed, even if uncertain, advice by speeding up publication of urgent policy-relevant information and hanging a bit looser on the certainty. We scientists live in the real world and have responsibilities to give the best possible advice, even if we run the risk of the occasional error or even some bias. Like Wally Broecker, we will be judged on our track record.

Climatic Change as a journal has moved with the times, with an increasing emphasis on policy-related research. It has also, due to its multi-disciplinary emphasis from the beginning discussed not just the physical science but also the potential impacts, economics and to some extent the policy implications. This trend must continue, especially with emphasis on the timeliness of papers in the world of policymaking. With the typical turn-around time for full refereed papers being around two years, the inception of Climatic Change Letters is a partial recognition of this need. The Letters section needs to be well-used to update the science and spell out its policy relevance, taking full account of the policy-making time-table in the real world.

Open Access This article is distributed under the terms of the Creative Commons Attribution Noncommercial License which permits any noncommercial use, distribution, and reproduction in any medium, provided the original author(s) and source are credited. 


\section{References}

Arrhenius S (1896) On the influence of carbonic acid in the air upon the temperature of the ground. Philos Mag 41:266

Broecker WS (1975) Climatic change: are we on the brink of a pronounced climatic warming. Science 189:460-464

Callendar GS (1938) The artificial production of carbon dioxide and its influence on temperature. Q J R Meteorol Soc 64:223-240

Federal Council for Science and Technology (1974) Report of the ad hoc panel on the present interglacial. Interdepartmental Committee for Atmospheric Science, ICAS 18B-FY75. Federal Council for Science and Technology, National Science Foundation, Washington, DC, 22 pp

IPCC (2009) See www.ipcc.ch for a brief history and mandate of the IPCC, and access to all its reports. IPCC, Geneva

Keeling C (1960) The concentration and isotopic abundances of carbon dioxide in the atmosphere. Tellus 12:200-203

Revelle R, Suess HE (1957) Carbon dioxide exchange between the atmosphere and ocean and the question of an increase of atmospheric $\mathrm{CO}_{2}$ during the past decades. Tellus 12:18-27

Schneider SH (2009) Science as a contact sport: inside the battle to save earth's climate. National Geographic Society. See www.nationalgeographic.com/books

SCOPE (1986) The greenhouse effect, climatic change, and ecosystems. SCOPE 29. Bolin B, Doos BR, Jaeger J, Warrick RA (eds) Wiley, Chichester, 541 pp

Toronto (1988) The Toronto conference report is briefly summarised in the UNFCCC climate change fact sheet 15. See also Zaelke and Cameron in American Journal of International Law and Policy 5(2):276-278 (1990)

Villach Conference (1985) Conference statement, available at www.icsu-scope.org/downloadpubs/ scope29/statement.html

WMO (1976) Statement on climate change. WMO, Geneva

WMO (1979) Statement is in First World Climate Conference, proceedings, Geneva, p 125. See also Environmental Law and Policy, no.5 (1979), p 65 and no.6 (1980), p 103, and climate change fact Sheet 213, UNEP information unit on climate change 